\title{
21. MARINE CRETACEOUS PALYNOLOGY OF HOLES 549 AND 550, DEEP SEA DRILLING PROJECT LEG 80, NORTHERN BAY OF BISCAY ${ }^{1}$
}

\author{
Danièle Fauconnier, Bureau de Recherches Géologiques et Minières, Orleans ${ }^{2}$
}

\begin{abstract}
Marine palynomorph assemblages occurring in 71 Cretaceous samples from DSDP Holes 549 and 550 are described in the present study. Owing to the relative scarcity of the palynomorphs recovered, the ages assigned are based more on individual occurrences than on assemblages.

In Hole 549, Barremian and Cenomanian forms were positively identified; the identification of Albian strata is based on the occurrence of a single species. Aptian forms could not be identified. In the uppermost Albian (Vraconian) of Hole 550, palynomorph recovery was poor, but it improved in the Cenomanian, where the assemblages are characteristic. The post-Cenomanian Upper Cretaceous also contains diagnostic species, but cannot be subdivided to the stage level.

Palynofacies variations suggest that the Barremian and the Albian were deposited in a coastal marine environment and that the lower Upper Cretaceous accumulated farther offshore under a much reduced terrigenous influence.
\end{abstract}

\section{INTRODUCTION}

Leg 80 of the Deep Sea Drilling Project was a concerted effort to study the geologic history of the North Atlantic Ocean before, during, and after the rifting that opened the ocean and separated Europe from North America. The coring program concentrated on four closely spaced sites on the continental margin seaward of the Western Approaches Basin. They are situated on Goban Spur about $250 \mathrm{~km}$ southwest of Ireland. This area was selected because the sedimentary section there is thin but is relatively complete.

\section{Hole 549}

Site 549 is above the seaward tip of a tilted basement high (water depth $2533 \mathrm{~m}$ ) near the Pendragon Escarpment, which truncates the westward slope of Goban Spur (Fig. 1). Hole 549 penetrated a 290 -m sequence of Barremian sedimentary rocks that accumulated rapidly during a marine transgression over the upraised basement rock. The succession consists principally of $150 \mathrm{~m}$ of noncalcareous terrigenous mudstones, interbedded with calcareous mudstones, overlain by $40 \mathrm{~m}$ of vuggy, diagenetically recrystallized, skeletal packstones and wackestones and $120 \mathrm{~m}$ of calcareous sandy mudstones.

A postrift unconformity separates the upper Barremian from the lower Albian. At the contact, an undated $7-\mathrm{m}$ bed of hard dolosparite is overlain by $185 \mathrm{~m}$ of gray calcareous lower and middle Albian siltstones. In the upper part, calcareous beds (as much as $\mathbf{8 3 \%}$ carbonate) alternate irregularly with clayrich beds (as little as $5 \%$ carbonate). The Upper Cretaceous is dominated by white chalks, but Turonian black shales are present in the lower part.

\footnotetext{
${ }^{1}$ Graciansky, P. C. de, Poag, C. W., et al., Init. Repts. DSDP, 80: Washington (U.S. Govt, Printing Office). France.
}

\section{Hole 550}

Site 550 is on the abyssal plain (water depth $4432 \mathrm{~m}$ ), $10 \mathrm{~km}$ southwest of the seaward edge of Goban Spur, above a high structural block of the oceanic basement (Fig. 1). Above the oceanic basement, the sedimentary sequence in Hole 550 begins with uppermost Albian (Vraconian) chalks at $685 \mathrm{~m}$. Overlying lower and middle Cenomanian sediments, consisting of interbedded light and dark mudstones, complete the sequence.

A disconformity occurs at $594.8 \mathrm{~m}$, and is indicated by a sharp contact between calcareous and noncalcareous sediments. The overlying interval consists of dark, massive, carbonate-free claystone (Santonian-Coniacian). Lower Maestrichtian (and late Campanian?) strata, from 575 to $426.5 \mathrm{~m}$, consist of interbedded calcareous turbiditic and mudflow deposits.

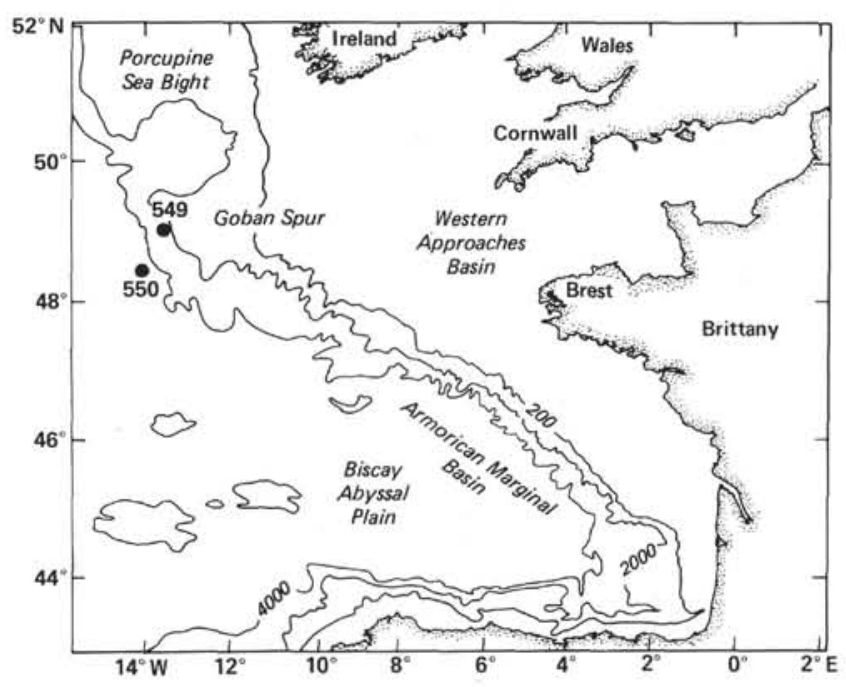

Figure 1. Locations of DSDP Holes 549 and 550. Contour depths in meters. 


\section{PALYNOLOGIC RESULTS}

Palynologic slides were prepared from 25 samples (17 cores) from Hole 549 and from 46 samples (34 cores) from Hole 550, and were studied for their marine palynomorph content.

\section{Hole 549}

In the Lower Cretaceous samples (Barremian and $\mathrm{Al}-$ bian), palynologic preparations are dominated by landderived plant debris and sporomorphs. Marine palynomorphs usually represent between 5 and $30 \%$ of the total palynomorph assemblage, although this figure may be as high as $45 \%$ (Sections 549-76-1 and 549-60-3). In the Cenomanian palynologic residue (Core 27), the marine palynomorph assemblage makes up a lower percentage, and sapropelic organic matter is abundant.

The stratigraphic distribution of palynomorphs from Hole 549 is plotted in Figure 2. In most cases, the species are represented by few specimens, and their preservation is relatively poor; most are transparent, and are often obscured by organic matter. For these reasons, the dinocysts present are difficult to use for precise stratigraphic interpretations; detailed correlations with other areas have not been attempted.

All the recovered dinocysts have been previously reported from samples from coeval sediments in northwest Europe (Davey, 1979a, Apto-Albian; Duxbury, 1980, Barremian) and in the western North Atlantic (Habib, 1977, Neocomian).

\section{Cores 79 to 53: Barremian}

Four long-ranging species, Spiniferites ramosus, Oligosphaeridium complex, Cyclonephelium distinctum, and $C$. brevispinatum, dominate the marine palynomorphs. Specimens of the genus Cyclonephelium are particularly abundant.

Some species are restricted to the Lower Cretaceous, notably Gonyaulacysta confossa, Dingodinium ?albertii, Meiourogonyaulax pertusa, Phoberocysta neocomica, Muderongia simplex microperforata, and Aprobolocysta neistosa, which are also present in the Lower Cretaceous Speeton Clay of England (Davey, 1974; Duxbury, 1977) and in Denmark (Davey, 1982). One other species, Druggidium deflandrei, is known only from the Barremian section, and occurs also in coeval sediments of southeast France (Millioud, 1969), and in the western North Atlantic (Habib, 1977).

Two stratigraphically important species found here are used in the dinocyst zonation (Davey, 1979b) of northwest Europe. The first is Odontochitina operculata, the base of which defines the zone of that name and encompasses most of the Barremian and more recent stages in the Cretaceous. The second is Palaeoperidinium cretaceum, which first occurs near the base of the mid-Barremian. So, in spite of low species diversity, the dinocysts confirm that this interval is Barremian.

\section{Cores 49 to 32: Albian}

The assemblages obtained from these cores are restricted: most of the samples are barren or contain only rare specimens. Most of the dinocyst species recovered in these cores were also present in the Barremian. Only four species first appear in this interval. Of these, $B a$ tioladinium sp. is characteristic of the Lower Cretaceous, Hystrichodinium pulchrum and Sensutidinium sp. are long-ranging forms, and Systematophora cretacea appears to be diagnostic for the middle and lower upper Albian (Davey, 1979a). The Albian cannot be well documented by means of dinocysts in these cores.

\section{Cores 28 through 27: Cenomanian}

In spite of a poor assemblage, the appearance of the two characteristic species, Palaeohystrichophora infusorioides and Epelidosphaeridia spinosa, in Section 27-1, indicates that these cores are uppermost Albian to Cenomanian.

\section{Upper Cretaceous Cores (25 to 19)}

All analyzed samples from these cores are completely barren of marine palynomorphs.

\section{Cretaceous Palynofacies in Hole 549}

The relative proportions of marine palynomorphs, spores, and pollen grains present in the palynologic residues of the samples studied are shown in Figure 3. This figure shows that spores and pollen grains are predominant in the Barremian and especially common in the Albian $(85-95 \%)$. This association, together with abundant terrestrial plant debris, suggests that the sediments were deposted not far from land.

Core 27, upper Cenomanian, is characterized by an abundance of amorphous palynodebris and a higher proportion of microplankton $(40 \%)$. This assemblage reflects a decreasing continental influence and a marine depositional environment.

\section{PALYNOMORPH SPECIES IN HOLE 549}

Aprobolocysta neistosa Duxbury, 1980 (Plate 1, Figs. 5 and 6) Batioladinium sp.

Callaiosphaeridium asymmetricum (Deflandre and Courteville, 1939) Davey and Williams, 1966

Cassiculosphaeridia reticulata Davey, 1969

Coronifera oceanica Cookson and Eisenack, 1958 (Plate 2, Fig. 7)

Cribroperidinium edwardsii (Cookson and Eisenack, 1958) Davey, 1969

Cyclonephelium brevispinatum (Millioud, 1969) Below, 1981 (Plate 2, Fig. 1)

Cyclonephelium distinctum Deflandre and Cookson, 1955

Dingodinium ?albertii Sarjeant, 1966 (Plate 2, Fig. 8)

Druggidium deflandrei (Millioud, 1969) Habib, 1973 (Plate 2, Figs. 2 and 3)

Epelidosphaeridia spinosa (Cookson and Hughes, 1964) Davey, 1969

Exochosphaeridium phragmites Davey et al., 1966

Florentinia mantellii (Davey and Williams, 1966) Davey and Verdier, 1973

Gardodinium trabeculosum (Gocht 1959) Alberti, 1961

Gonyaulacysta aptiana (Deflandre, 1935) Sarjeant, 1966 (Plate 1, Fig. 4)

Gonyaulacysta confossa Duxbury, 1977

Gonyaulacysta helicoidea (Eisenack and Cookson, 1960) Sarjeant, 1966

Hystrichodinium pulchrum Deflandre, 1935 (Plate 2, Fig. 6)

Hystrichosphaerina schindewolfii Alberti, 1961

Kiokansium polypes (Cookson and Eisenack, 1962) Davey, 1983

Meiourogonyaulax pertusa (Duxbury, 1977) Below, 1981 (Plate 1, Fig. 7)

Muderongia simplex (Alberti, 1961) subsp. microperforata Davey, 1982 (Plate 1, Fig. 8)

\footnotetext{
${ }^{3}$ In alphabetic order by genus and species. Plate and figure numbers indicate species illustrated in this chapter.
} 


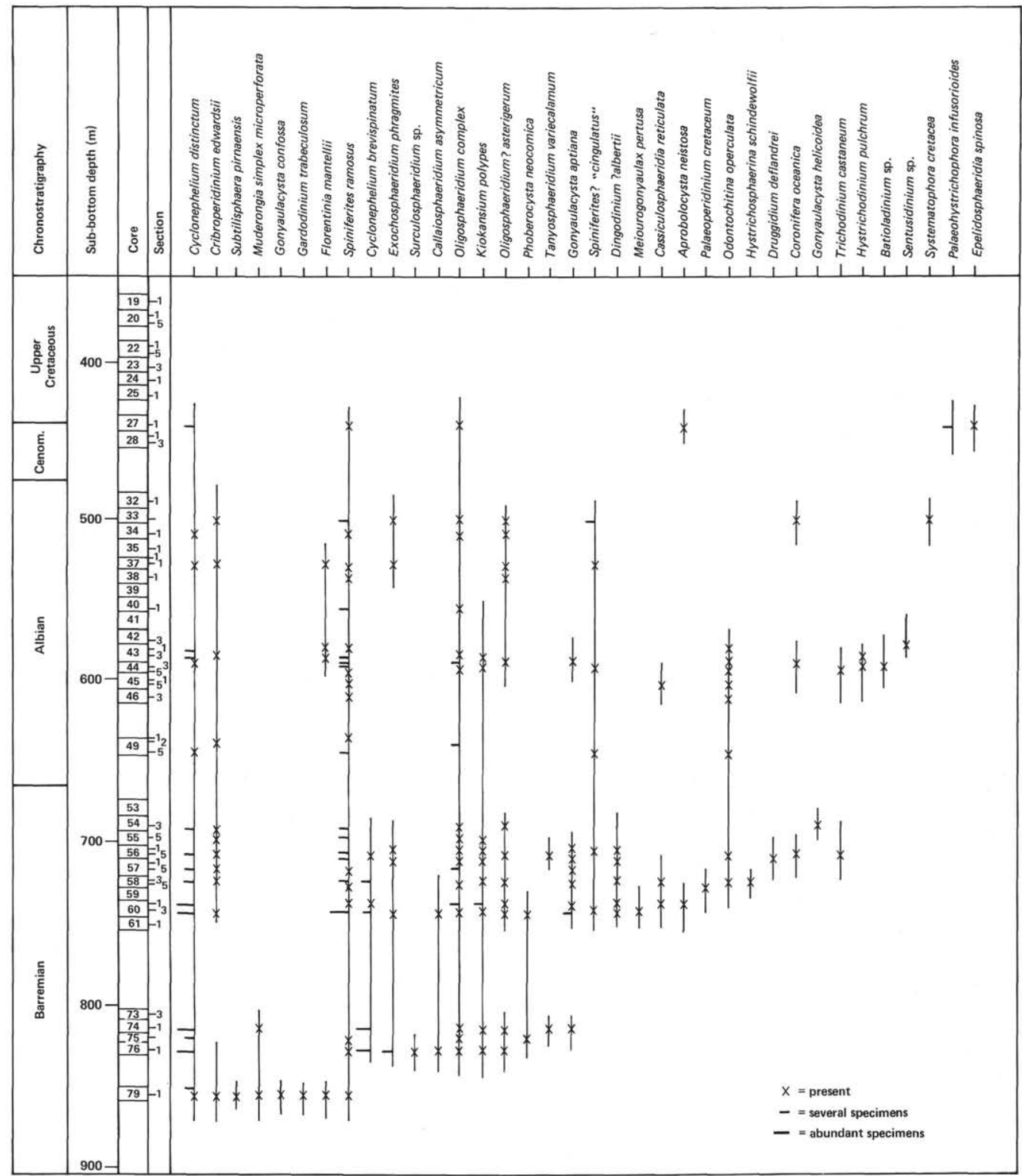

Figure 2. Distribution of Cretaceous marine palynomorphs, Hole 549. 


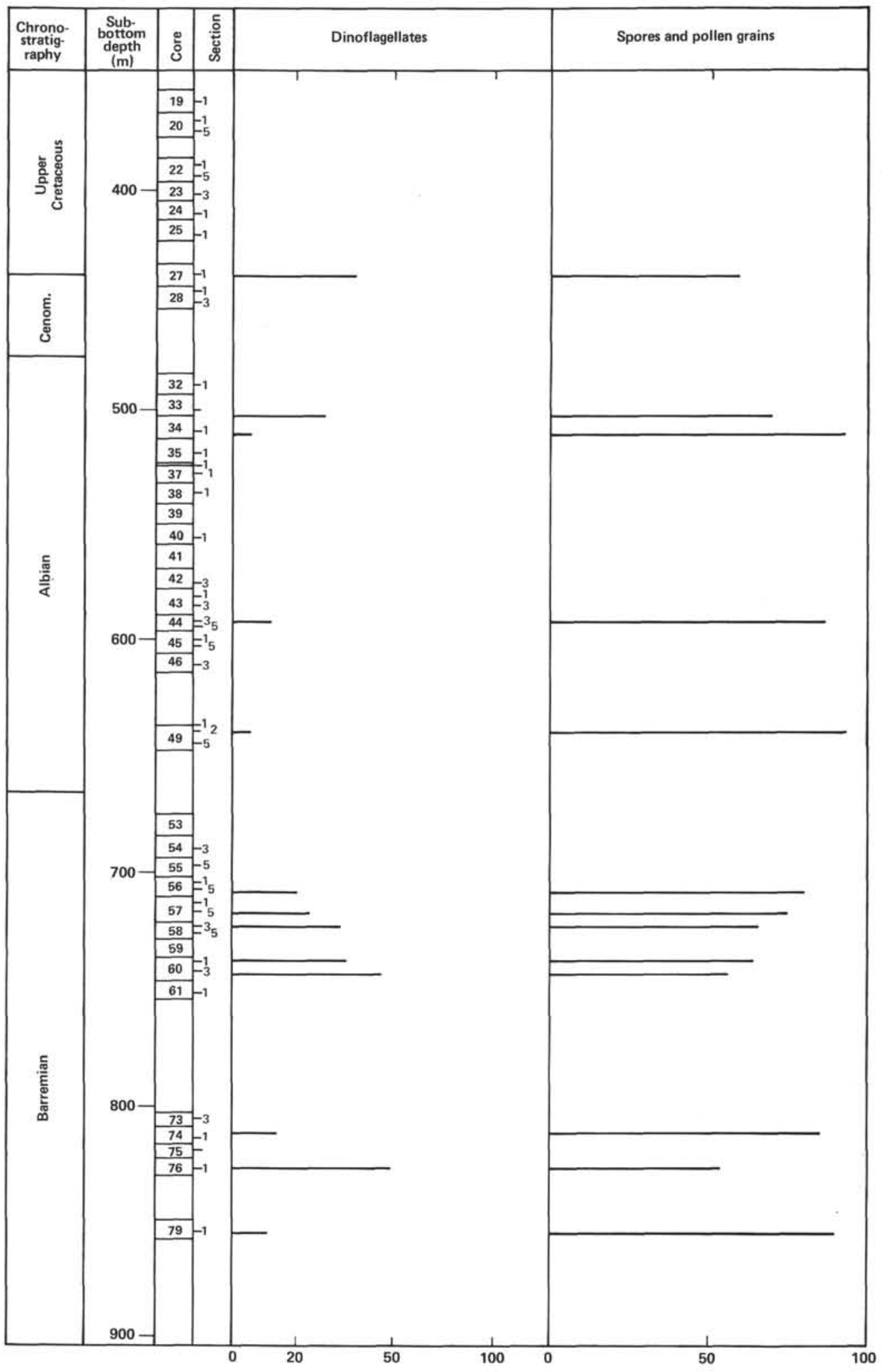

Figure 3. Relative abundances (\%) of dinoflagellates, spores, and pollen grains, Hole 549. 
Odontochitina operculata (Wetzel, 1933) Deflandre and Cookson, 1955 (Plate 1, Fig. 2)

Oligosphaeridium ?asterigerum (Gocht, 1959) Davey and Williams, 1969

Oligosphaeridium complex (White, 1942) Davey and Williams, 1966 Palaeohystrichophora infusorioides Deflandre, 1935

Palaeoperidinium cretaceum Pocock, 1962

Phoberocysta neocomica (Gocht, 1957) Millioud, 1969

Pterodinium cingulatum (Wetzel, 1933) Below, 1981

Sentusidinium sp.

Spiniferites? "cingulatus" (Wetzel, 1933) Sarjeant, 1970

Spiniferites ramosus (Ehrenberg, 1838) Loeblich and Loeblich, 1966

Subtilisphaera pirnaensis (Alberti, 1959) Jain and Millepied, 1973 (Plate 1, Fig. 3)

Surculosphaeridium sp.

Systematophora cretacea Davey, 1979 (Plate 2, Figs. 4 and 5)

Tanyosphaeridium variecalamum Davey and Williams, 1966

Trichodinium castaneum (Deflandre, 1935) Clarke and Verdier, 1967

\section{Hole 550B}

The analyzed palynologic slides analyzed from the upper Albian samples (Cores 25 to 22) contain dark sapropelic organic matter, rare terrestrial plant debris, and rare marine species. Sapropelic organic matter and sporomorphs become abundant in the middle Cenomanian samples; marine palynomorphs represent less than $15 \%$ of the palynomorph assemblage. Above this level, in Cores 14 and 13, amorphous organic matter, continental plant debris, and dinocysts are more abundant, and sporomorphs decrease markedly. From Core 12 upward, the samples are barren and contain little organic matter.

The stratigraphic distribution of the marine palynomorphs from Hole 550 is plotted in Figure 4. The occurrence of microplankton is very limited in the lower part of the sequence (Cores 25 to 18). In the middle part (Cores 17 to 13) dinocysts are more abundant, and 41 species were recovered. In the upper part (Cores 12 to 6), only two species were encountered, in Section 10-4. All dinocyst species present at this hole are known to occur in northwest Europe and/or in Canada (Manun and Cookson, 1964; McIntyre, 1975) and in California (Drugg, 1967).

\section{Cores 25 to 22: Uppermost Albian (Vraconian)}

The assemblages from these cores contain only seven taxa, and thus show relatively little diversity. No detailed stratigraphic conclusions can be drawn.

\section{Cores 21 to 15: Cenomanian}

The following three long-ranging species dominate the marine palynomorph assemblages: Cyclonephelium distinctum, Spiniferites ramosus, and Odontochitina operculata. In spite of the limited diversity of the microplankton (22 species in 10 samples), the five species Palaeohystrichophora infusorioides, Leberidocysta chlamydata, Epelidosphaeridia spinosa, Litosphaeridium siphoniphorum, and Florentinia deanei indicate that the sediments from Core 17 upward are uppermost Albian to Cenomanian.

\section{Cores 14 to 6: Upper Cretaceous}

Cores 14 and 13 are the most palyniferous of the samples analyzed. The same species as in the lower cores already discussed are usually present, and dominate some assemblages. These are Cyclonephelium distinctum, Odontochitina operculata, Spiniferites ramosus, and $\mathrm{Pa}$ laeohystrichophora infusorioides. However, Litosphaeridium siphoniphorum, limited to the uppermost Albian to Cenomanian, is no longer present.

In addition, 18 species appear in these cores, six of which characterize the Upper Cretaceous: Chatangiella victoriensis, C. granulifera, Laciniadinium arcticum, and Isabelidinium cf. acuminatum occur in the Upper Cretaceous of Arctic Canada (Manum and Cookson, 1964); Elytrocysta druggii and Palaeoperidinium pyrophorum, are present in the Upper Cretaceous of California (Drugg, 1967). C. victoriensis has also been found in the Turonian of France (Foucher, 1982) and in the Santonian of England (Clarke and Verdier, 1967). The other species found in these cores have also been previously reported for samples predating the Upper Cretaceous.

With the exception of the two species found in Core 10 , the samples from Cores 12 to 6 are barren.

\section{Cretaceous Palynofacies in Hole 550}

Figure 5 presents the relative proportions of dinoflagellates, spores, and pollen grains determined in the palynologic residues of the samples studied. In the Vraconian (uppermost Albian), the microplankton assemblages are too limited to be represented on the figure, and the paleoenvironment cannot be determined precisely, though it was certainly marine. In the Cenomanian, Cores 17 and 16 contain a mixture of sapropelic organic matter, abundant sporomorphs $(80-85 \%)$, and terrestrial plant debris. These characteristics suggest marine sedimentation influenced by terrestrial sources. Higher in the Upper Cretaceous, Cores 14 and 13, microplankton and amorphous organic matter dominate the assemblages, whereas sporomorphs decrease. I interpret this to mean that neighboring land-masses had less influence during this period of deposition.

\section{PALYNOMORPH SPECIES IN HOLE 550}

Achomosphaera ramulifera (Deflandre, 1937) Evitt, 1963 Apteodinium cf. maculatum Eisenack and Cookson, 1960 Callaiosphaeridium asymmetricum (Deflandre and Courteville, 1939) Davey and Williams, 1966

Canningia ?ringnesiorum Manum and Cookson, 1964

Chatangiella victoriensis (Cookson and Manum, 1964) Lentin and Williams, 1976 (Plate 3, Fig. 5)

Chatangiella granulifera (Manum, 1963) Lentin and Williams, 1976 (Plate 3, Fig. 6)

Chlamydophorella nyei Cookson and Eisenack, 1958

Cleistosphaeridium huguoniotii (Valensi, 1955) Davey, 1969

Coronifera oceanica Cookson and Eisenack, 1958

Coronifera striolata (Deflandre, 1937) Stover and Evitt, 1978

Cribroperidinium edwardsii (Cookson and Eisenack, 1958) Davey, 1969

Cyclonephelium distinctum Deflandre and Cookson, 1955

Elytrocysta druggii Stover and Evitt, 1978 (Plate 3, Fig. 4)

Epelidosphaeridia spinosa (Cookson and Hughes, 1964) Davey, 1969

Exochosphaeridium phragmites Davey et al., 1966

Florentinia deanei (Davey and Williams, 1966) Davey and Verdier, 1973

Hystiocysta palla Davey, 1969 (Plate 3, Fig. 2)

\footnotetext{
${ }^{4}$ In alphabetic order by genus and species. Plate and figure numbers indicate species illustrated in this chapter.
} 


\section{FAUCONNIER}

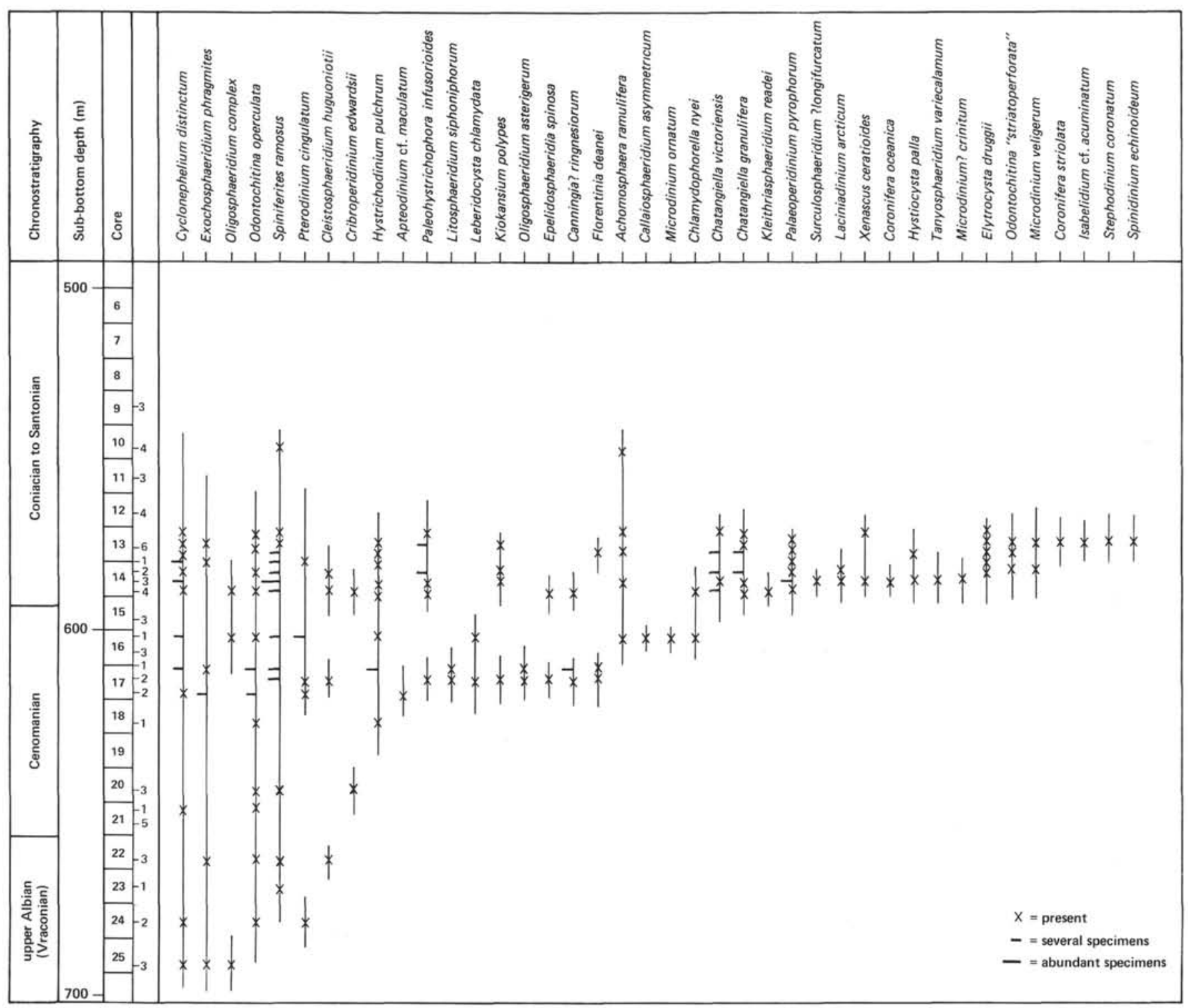

Figure 4. Distribution of marine palynomorphs, Hole 550.

Hystrichodinium pulchrum Deflandre, 1935

Isabelidinium cf. acuminatum (Cookson and Eisenack, 1958) Stover and Evitt, 1978

Kleithriasphaeridium readei (Davey and Williams, 1966) Davey and Verdier, 1976

Kiokansium polypes (Cookson and Eisenack, 1962) Davey, 1983

Laciniadinium arcticum (Manum and Cookson, 1964) Lentin and Williams, 1980 (Plate 3, Fig. 3)

Leberidocysta chlamydata (Cookson and Eisenack, 1962) Stover and Evitt, 1978 (Plate 3, Fig. 7)

Litosphaeridium siphoniphorum (Cookson and Eisenack, 1958) Davey and Williams, 1966

Microdinium? crinitum Davey, 1969

Microdinium cf. ornatum Cookson and Eisenack, 1960

Microdinium veligerum (Deflandre, 1937) Davey, 1969 (Plate 3, Fig. 1)

Odontochitina operculata (Wetzel, 1933) Deflandre and Cookson, 1955 Odontochitina "striatoperforata" Cookson and Eisenack, 1962 (Plate 3, Fig. 10)

Oligosphaeridium ?asterigerum (Gocht, 1959) Davey and Williams, 1969
Oligosphaeridium complex (White, 1842) Davey and Williams, 1966 Palaeohystrichophora infusorioides Deflandre, 1935

Palaeoperidinium pyrophorum (Ehrenberg, 1838) Sarjeant, 1967 (Plate 3, Figs. 8 and 9)

Pterodinium cingulatum (Wetzel, 1933) Below, 1981

Spinidinium echinoideum (Cookson and Eisenack, 1960) Lentin and Williams, 1976

Spiniferites ramosus (Ehrenberg, 1938) Loeblich and Loeblich, 1966 Stephodinium coronatum Deflandre, 1936

Surculosphaeridium ?longifurcatum (Firtion, 1952) Davey et al., 1966

Tanyosphaeridium variecalamum Davey and Williams, 1966

Xenascus ceratioides (Deflandre, 1937) Lentin and Williams, 1973

\section{ACKNOWLEDGMENTS}

I thank P. C. de Graciansky, Co-Chief Scientist of Leg 80, who kindly gave me the opportunity to take part in this study and provided the necessary samples. I am very pleased to acknowledge the critical reviews of R. J. Davey and D. J. Batten.

This study was supported by ATP IPOD (Action Thématique Programme IPOD of the French Centre National de la Recherche Scientifique). 


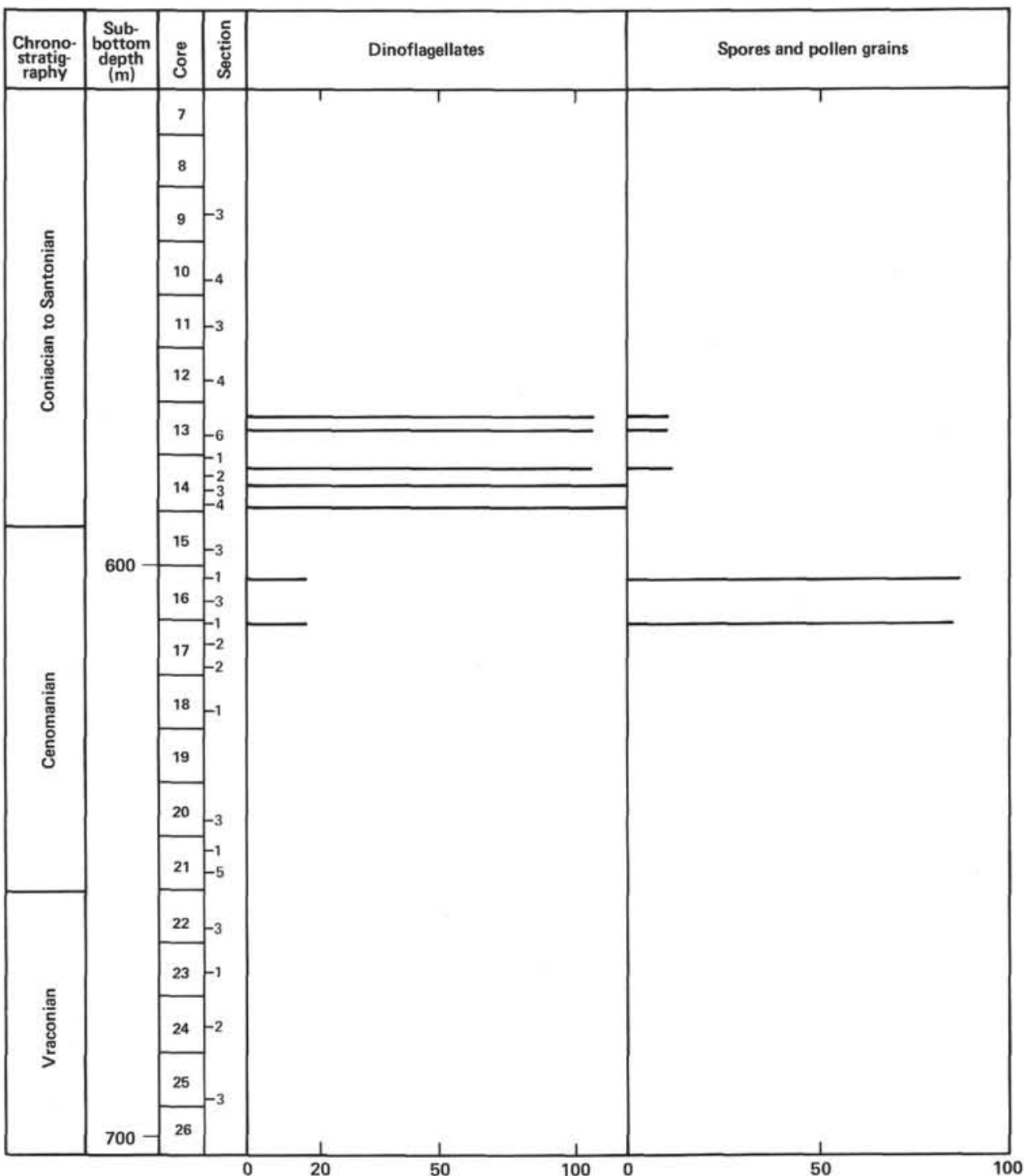

Figure 5. Relative abundances (\%) of dinoflagellates, spores, and pollen grains, Hole 550.

\section{REFERENCES}

Clarke, R. F. A., and Verdier, J. P., 1967. An investigation of microplankton assemblages from the chalk of the Isle of Wight, England. Verh. K. Ned. Akad. Wet. Afd. Natuurkd., Kd., Reeks 1, 24:1-96.

Davey, R. J., 1974. Dinoflagellate cysts from the Barremian of the Speeton Clay, England. In Symposium on Stratigraphic Palynolo$g y$, Spec. Pub. Birbal Sahni Inst. Palaeobotany, 3:41-75.

1979a. Marine Apto-Albian palynomorphs from Holes 400A and 402A, IPOD, Leg 48, Northern Bay of Biscay. In Montadert, L., Roberts D. G., et al., Init. Repts. DSDP, 48: Washington (U.S. Govt. Printing Office), 547-577.

1979b. The stratigraphic distribution of dinocysts in the Portlandian (latest Jurassic) to Barremian (Early Cretaceous) of northwest Europe. Am. Assoc. Stratigraphic Palynologists Contrib. 5B:49-81.

1982. Dinocyst stratigraphy of the latest Jurassic to Early Cretaceous of the Haldager $\mathrm{n}^{\circ} 1$ borehole, Denmark. Geol. Surv. Den. Ser. B (6): 1-56.

Drugg, W.S., 1967. Palynology of the Upper Morena Formation (Late Cretaceous-Paleocene), Escarpado Canyon, California. Palaeontographica, 120:1-71.

Duxbury, S., 1977. A palynostratigraphy of the Berriasian to Barremian of the Speeton Clag of Speeton, England. Palaeontographica, 160:17-67.
1980. Barremian phytoplankton from Speeton, east Yorkshire. Palaeontographica, 173:107-146.

Foucher, J. C., 1982. Dinoflagellés et acritarches du Saumurois. In Robaszynski, F. (Coord.), Alcaydé, G., Amédro, F., et al., Le Turonien de la Région Type. Bull. Cent. Rech., Explor. Prod. ElfAquitaine, 6:147-150.

Habib, D., 1977. Comparison of Lower and middle Cretaceous palynostratigraphic zonations in the western North Atlantic. In Swain, F. M. (Ed.), Stratigraphic Micropaleontology of Atlantic Basin and Borderlands (Vol. 6): New York (Elsevier), pp. 341-367.

McIntyre, D. J., 1975. Morphologic changes in Deflandrea from a Campanian section, District of Mackenzie, N.W.T., Canada. Geoscience and Man, 11:61-76.

Manum, S., and Cookson, I. C., 1964. Cretaceous microplankton in a sample from Graham island, Arctic Canada, collected during the second "Fram"-Expedition (1898-1902). Skr. Nor. Vidensk. Akad. Kl. I: Mat. Naturvidensk. Kl., 17:1-35.

Millioud, M. E., 1969. Dinoflagellates and acritarchs from some western European Lower Cretaceous type localities. In Bronniman, P., and Renz, H. H. (Eds.), Proc. First Internat. Conf. Planktonic Microfossils, 2: Leiden (E. J. Brill), pp. 420-434.

Date of Initial Receipt: February 11, 1983 Date ofAcceptance: May 16, 1983 

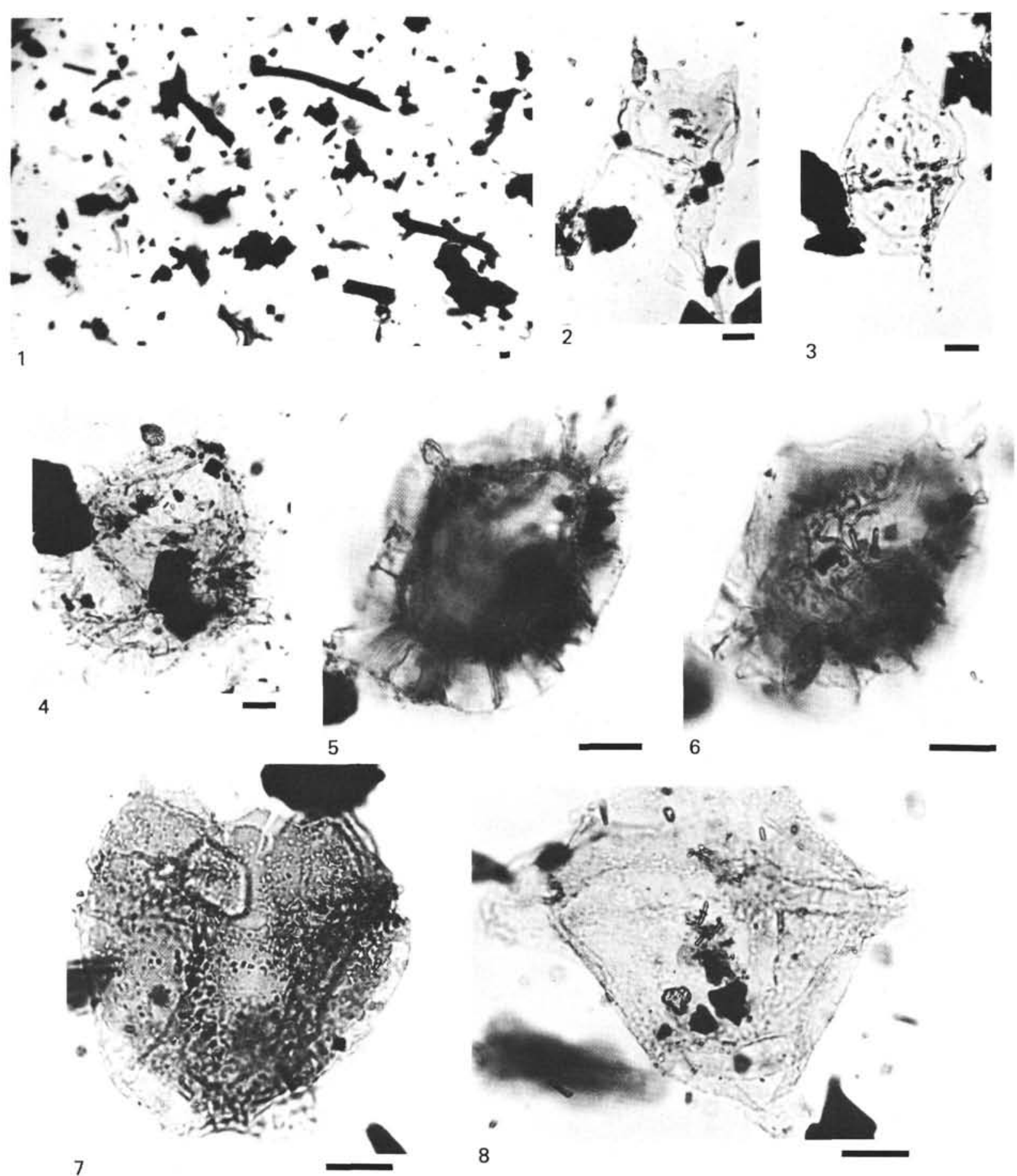

Plate 1. Hole 549; scale bar $=10 \mu \mathrm{m}$. 1. Palynofacies (terrestrial plant debris) $(\times 100)$, Section $549-76-1$. 2. Odontochitina operculata $($ Wetzel $)$ Deflandre and Cookson, $1955(\times 500)$, Section 549-58-3. 3. Subtilisphaera pirnaensis (Alberti) Jain and Millepied, $1973(\times 500)$, Section 549-79-1. 4. Gonyaulacysta aptiana (Deflandre) Sarjeant, $1966(\times 500)$, Section 549-58-3. 5, 6. Aprobolocysta neistosa Duxbury, 1980 ( $\times 1000)$, Section 549-60-1, (5) dorsal view, apical archaeopyle, (6) ventral view, ornamentation. 7. Meiourogonyaulax pertusa (Duxbury) Below, 1981 ( $\times 1000$ ), Section 549-60-3. 8. Muderongia simplex subsp. microperforata (Alberti) Davey, 1982 ( $\times 1000)$, Section 549-74-1. 

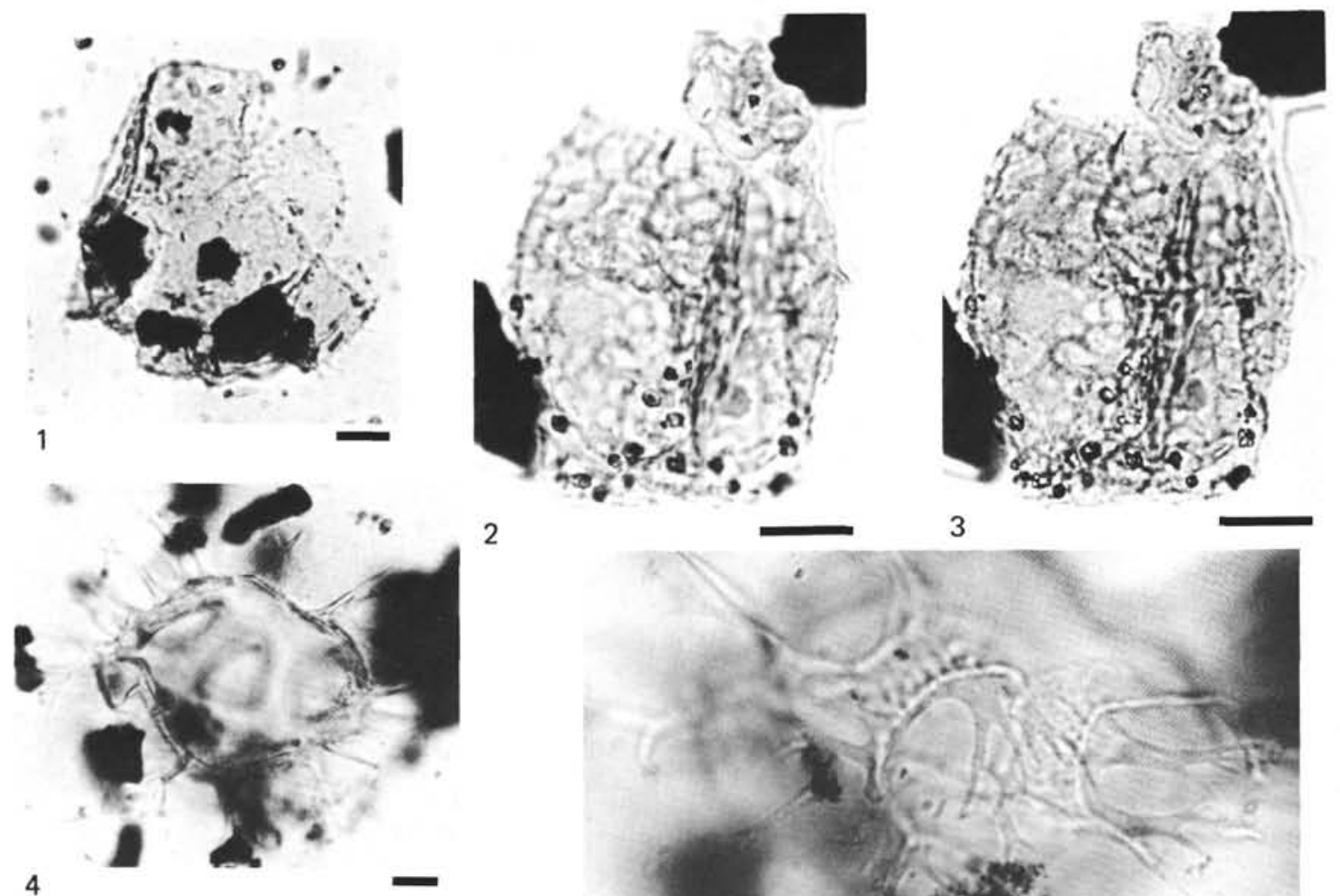

2
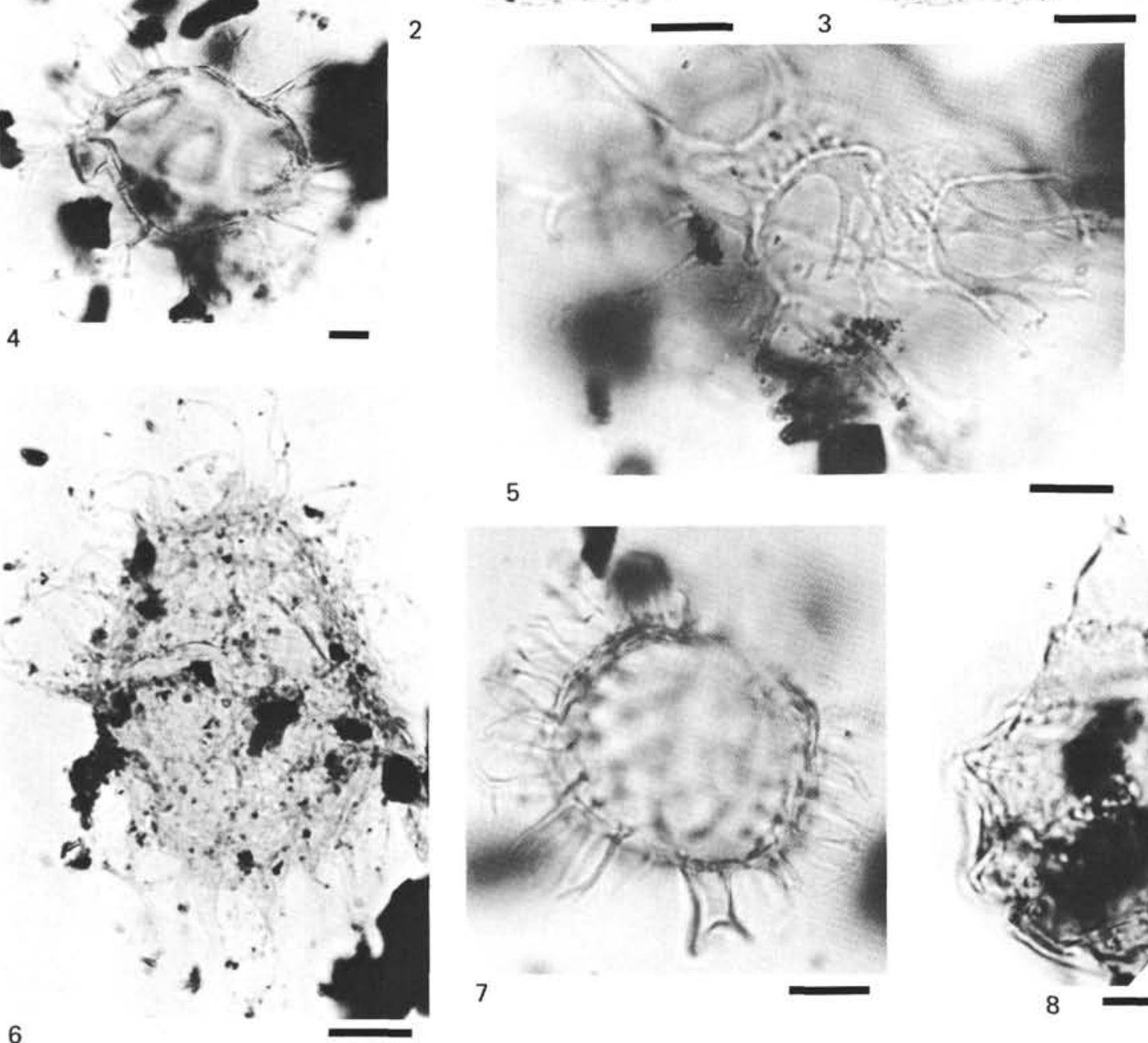

5
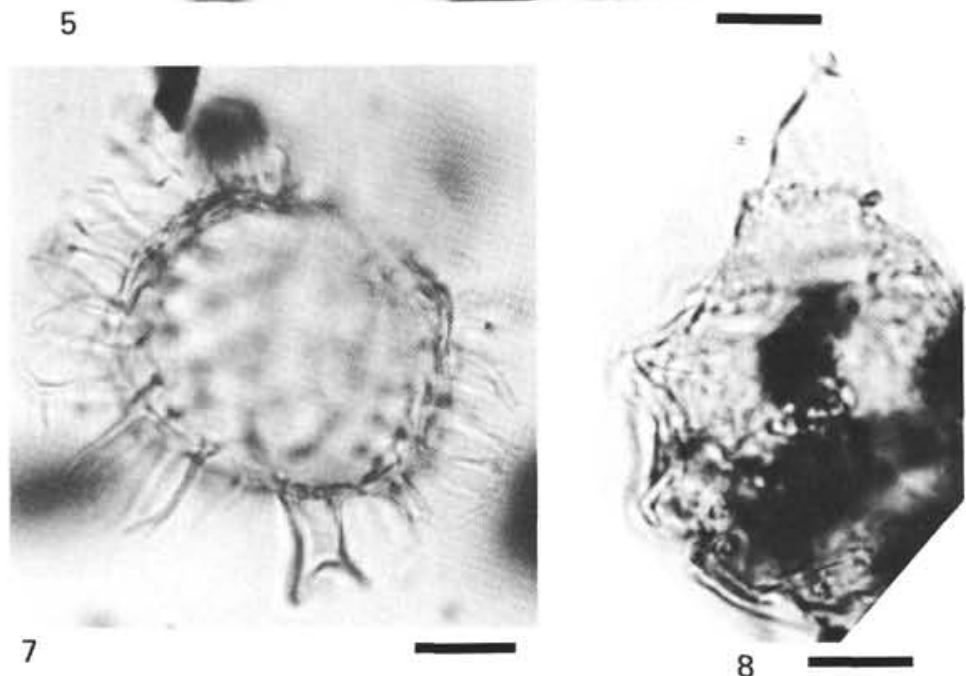

Plate 2. Hole 549; scale bar $=10 \mu \mathrm{m}$; unless otherwise indicated, magnification is $\times 1000 . \quad 1$. Cyclonephelium brevispinatum (Millioud) Below, 1981 ( $\times 500$ ), Section 549-58-3. 2, 3. Druggidium deflandrei (Millioud) Habib, 1973 (Section 549-44-5), detached operculum, (2) dorsal view, (3) ventral view. 4, 5. Systematophora cretacea Davey, 1979 (Section 549-33,CC), (4) $\times 500$ dorsal view apical archaeopyle, (5) detail, ornamentation of processus. 6. Hystrichodinium pulchrum Deflandre, 1935 (Section 549-44-3). 7. Coronifera oceanica Cookson and Eisenack, 1958 (Section 549-56-5). 8. Dingodinium ?albertii Sarjeant, 1966 (Section 549-60-1). 

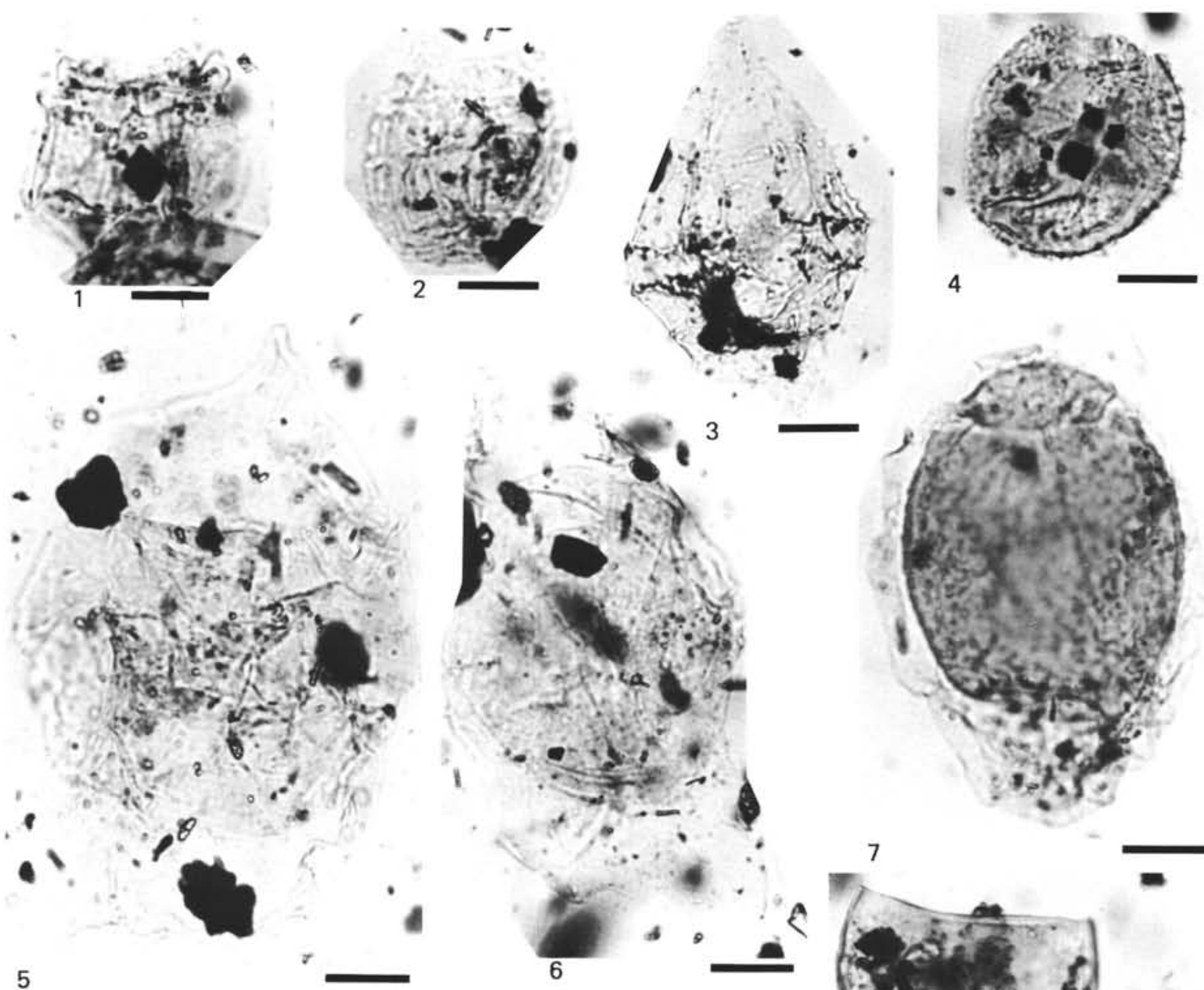

5
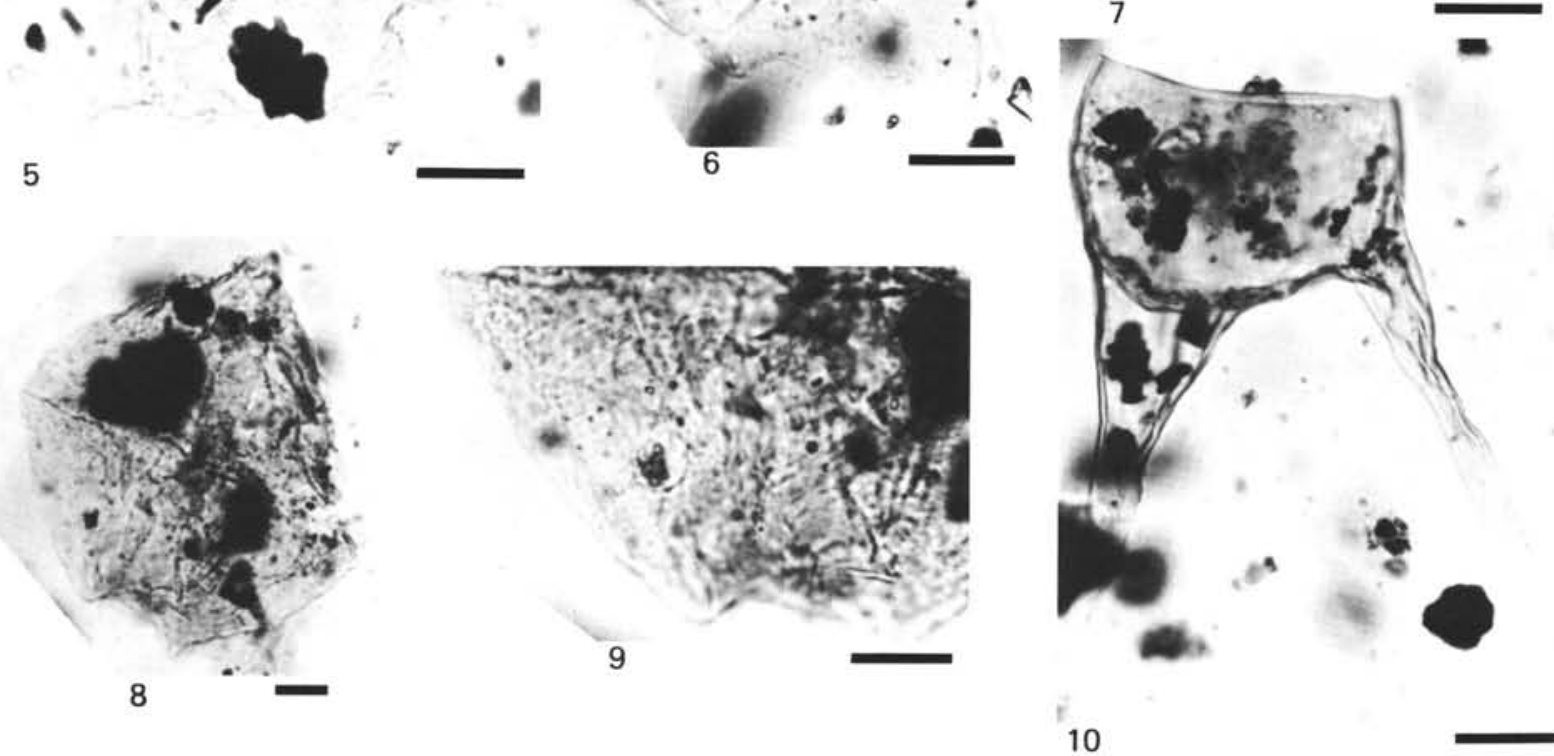

Plate 3. Hole 550; scale bar $=10 \mu \mathrm{m}$; unless otherwise indicated, magnification is $\times 1000$. 1. Microdinium veligerum (Deflandre) Davey, 1969 (Section 550-13-6). 2. Hystiocysta palla Davey, 1969 (Section 550-13-6). 3. Laciniadinium arcticum (Manum and Cookson) Lentin and Williams, 1980 (Section 550-14-2). 4. Elytrocysta druggii Stover and Evitt, 1978 (Section 550-13-6). 5. Chatangiella victoriensis (Cookson and Manum) Lentin and Williams, 1976 (Section 550-14-4). 6. Chatangiella granulifera (Manum) Lentin and Williams, 1976 (Section 550-14-4). 7. Leberidocysta chlamydata (Cookson and Eisenack) Stover and Evitt, 1978 (Section 550-17-2). 8, 9. Palaeoperidinium pyrophorum (Ehrenberg, 1838) Sarjeant, 1967, (8) $\times 500$, (9) detail of ornamentation. 10. Odontochitina "striatoperforata" Cookson and Eisenack, $1962(\times 500)$, Section 550-13-6. 